\title{
DOCUMENTATION OF SOME CULTURAL HERITAGE EMERGENCIES IN SYRIA IN AUGUST 2010 BY SPHERICAL PHOTOGRAMMETRY
}

\author{
Gabriele Fangi
}

Università Politecnica delle Marche - Italy, gabrielefangi@gmail.com

KEY WORDS: Syrian Cultural Heritage, war, emergency, panoramic spherical photogrammetry

\begin{abstract}
:
Syria is a country of many civilizations, Marie, Aramaic, Phoenician, Roman, Byzantine, Islamic, Ottoman civilizations. Unfortunally the recent war is the reason for many cultural heritage items to be destroyed, beyond the thausand civilian people killed. In 2010, just before the war, the A. made a touristic trip together with Crua (Recreational Club of the Ancona University). It was the occasion to make some fast documentation of some Syrian $\mathrm{CH}$ monuments. Mostly of the images were taken by the A. not to make a survey, but as a photographic report, as fast and complete as possible. For a regular survey project, the tripod, the spherical head should be used for the takings and the $3 \times 3$ Cipa rules should be followed, that occurred only in the three main projects, say the survey of the citadel walls in Aleppo, the survey of the Umayyads Mosque in Damascus, and the survey of the minaret of the Umayyads Mosque in Aleppo. All the other documentation surveys have been carried out with hand-held camera taking the dimension of the model from Google earth high resolution, when available. But, apart the regular surveys, due to the explosion of the unexpected war, the photographs taken in such a touristic way, have been used to try to get some usable plottings an restitutions and it worked successfully mostly of the times. These surveys could be useful in case of reconstruction and in case of lack of suitable alternative metric documentation. Because of the continuing threats, all six Syrian World Heritage properties were inscribed on the List of World Heritage in Danger, at the 37th session of the World Heritage Committee, held in Cambodia last June: Ancient City of Aleppo, Ancient City of Bosra, Ancient City of Damascus, Ancient Villages of Northern Syria, Krak des Chevaliers and Qal'at Salah El-Din ans finally the Site of Palmyra. See the following links: https://www.youtube.com/watch?feature=player_embedded\&v=kr. a3e0DL5sA and https://www.youtube.com/watch?v=ltFFjjrUgtU. Apart the Ancient Villages of Northern Syria, the A. visited all the World Heritage sites and partly documented. Some of them have already been plotted, some are in the orientation stage, some have been documented only.
\end{abstract}

\section{INTRODUCTION}

\subsection{The Syrian Cultural Heritage}

Syria is a country of many civilizations, Marie, Aramaic, Phoenician, Roman, Byzantine, Islamic, Ottoman civilizations. Unfortunally the recent war, beyond the thousand of civilian people killed, is the reason for many cultural heritage monuments, to be destroyed. Aleppo and Damascus are among the oldest human settlements of the world. "So called "the crossroad of ancient cultures",Syria is located at the heart of ancient trail routes cutting from north to south and from the Far East to the Eastern Mediterranean and beyond (Figure 1). The ancient Near East is the place where major societal changes occurred i rst, and Syria (like Iraq) is characterized by two key issues which are at the base of our modern life: the Neolithic transformations with the introduction of sedentary life and early agriculture, and the emergence of urban societies, writing systems and empires attested in sites such as Tell Hamoukar, Abu Hureyra, Ebla, Damascus, Palmyra and Aleppo, to name but a few." (P.Brasasco,2012).

In August 2010, just before the war, the A. made a touristic trip together with Crua (Recreational Club of the Ancona

University). It was the occasion to make some fast documentation of Syrian CH. Mostly of the pictures were taken not to make a regular survey of documentation, but as a simple and quick photographic report, as large as possible. Because of the continuing threats, all six Syrian World Heritage properties were inscribed on the List of World Heritage in Danger, at the 37th session of the World Heritage Committee, held in Cambodia last June: Ancient City of Aleppo, Ancient City of Bosra, Ancient City of Damascus, Ancient Villages of Northern Syria, Krak des Chevaliers and Qal'at Salah El-Din and finally the Site of Palmyra. See the following links: https://www.youtube.com/watch?feature=player_embedded\&v= kr. 3e0DL5sA,https://www.youtube.com/watch?v=ltFFjjrUgtU.

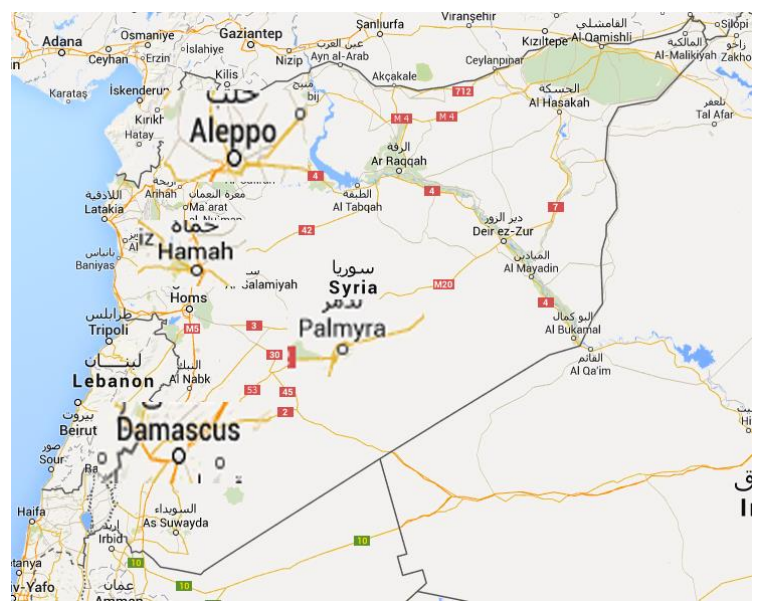

Figure 1. Syria Damascus, Shabba, Bosra, Hamah, Palmyra and Aleppo are the visited cities 


\subsection{The Panoramic Spherical Photogrammetry}

Spherical Photogrammetry is a technique set-up by the A. making use of spherical panoramas as image support. The advantages are the high resolution, the FOV up to $360^{\circ}$, the low cost, the completeness of the information and the high speed of takings. On the contrary, the plotting and the orientation are slow and up to now, fully manual. There exist today tools and instruments more accurate and efficient for $\mathrm{CH}$ recording like laser scanning, but the goal of SP is to allow anybody to make documentation everywhere with simple and low-cost means. Technical details can be found in (Fangi, Nardinocchi, 2012).

\section{THE DOCUMENTATION}

For the sake of semplicity we distinguish the documentation in two parts, the rigorous surveys and the quick documentation. The used camera was a Canon 60D equipped with 24, 50, 200 $\mathrm{mm}$ lenses. The photographs shown in this article are spherical panoramas. A Leica Disto was used for distance measurements. The software used for stitching was Ptgui 9. The orientation and the plotting have been performed with the non-commercial Sphera package developed by the A. All the restitutions, the plottings, the renders have been done by the students of the course of Photogrammetry at the Università Politecnica della Marche, Ancona, Italy. In this paper the projects already plotted only are shown while the remaing ones are still undegoing the restitution. Any of the students has a different skill, sensibility, normally they are completely new to photogrammetry thus justifies the different quality of the different projects. All the surveys are only partial surveys, deriving from a quick documentation. Some plots are limited to the wire-frame model, some have been textured with the same photographs used for the panoramas.

\subsection{The quick documentation}

Below the documented monuments are listed.

\subsubsection{The Damascus Region}

The Darvikya mosque, the Al Sybahieh Mosque, Qasr al-Heir al Gharbi gate, (the entrance gate of the National Museum), Hamah, the minaret of Noria-al-Muhammad mosque, Krak des Chevaliers.

\subsubsection{The Roman Heritage}

Bosra the roman theatre, Shabba the roman forum, the roman theatre, Apamea, a roman temple,

Palmira the roman temple, a triumphal arch, a monumental tomb

\subsubsection{The Aleppo Region}

The Clock tower in Aleppo, the Saint Simeon Stylite church, Arch, Al Helwieh madrasa façade, mihareb inside the citadel.

\subsection{The rigorous surveys}

The following surveys have been performed with tripod, spherical head, following the $3 \times 3$ Cipa rules.
2.2.1 The Omayyad mosque in Damascus

2.2.2 The walls of the Ciatadel in Aleppo

2.2.3 The Minaret of the Omayyad mosque in Aleppo

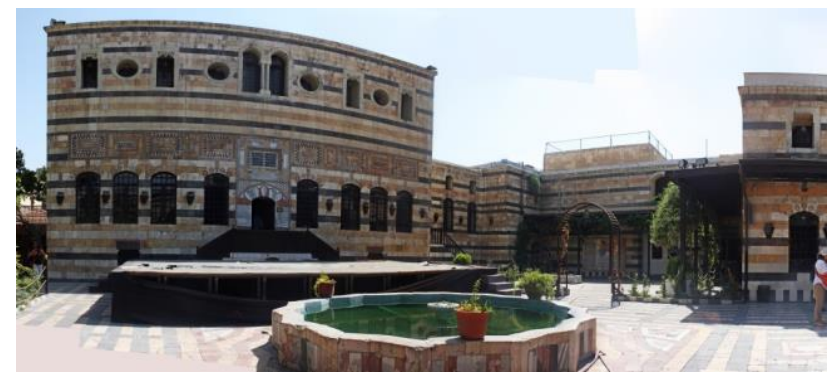

Figure 2 - Damascus, Al Azem Palace

The architecture is an excellent example of Damaschen traditional masonry, build in the half of $18^{\circ} \mathrm{c}$. The façade here shown is composed by several types of marbles and stones, like black basalt and limestone.

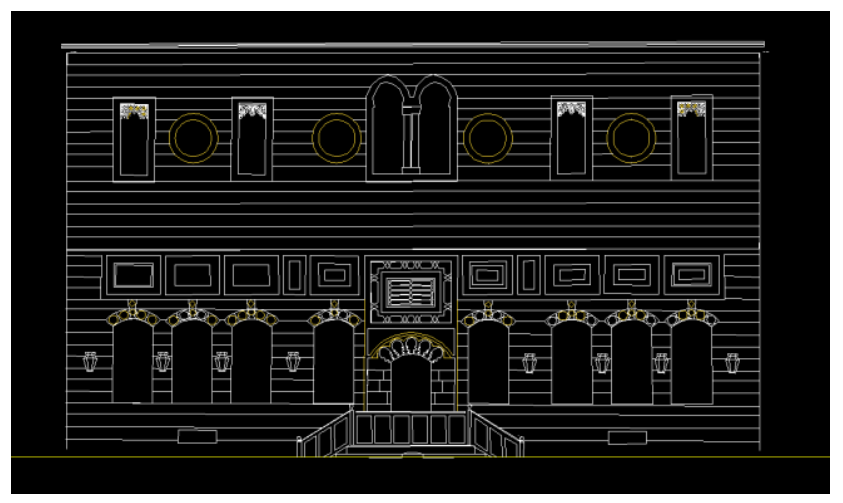

Figure 3 - The Al Azem Palace façade (plot by F.DiStefano produced with two spherical panoramas)

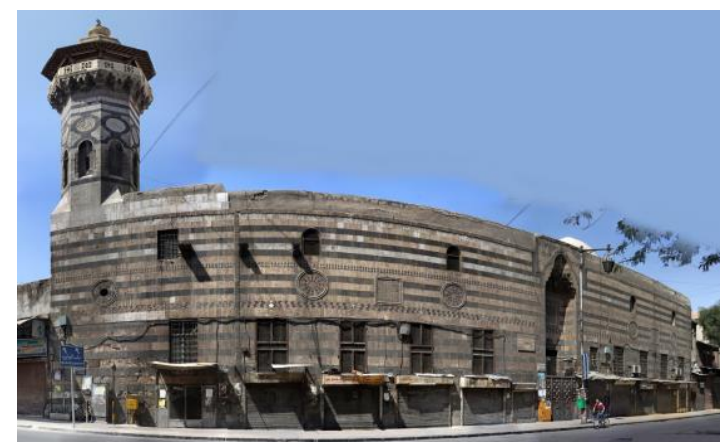

Figure 4 - Damascus - Al Sybahieh Mosque

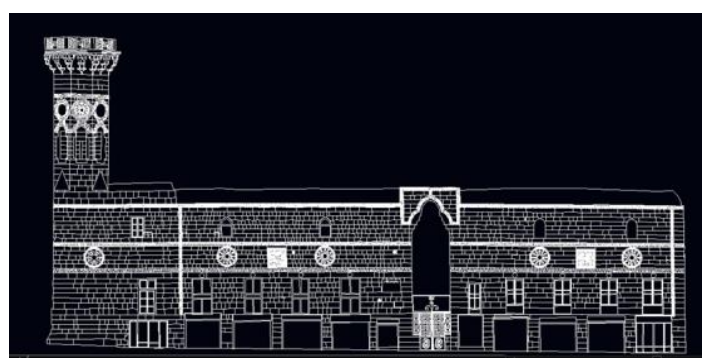


Figure 5 - Al Sybahieh Mosque (plot. By G.Merlonetti with four panoramas)

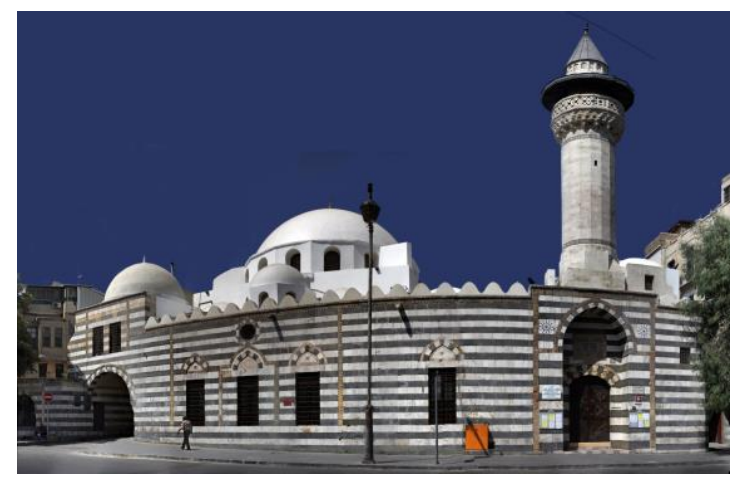

Figure 6 - Damascus, al Darwikiya Mosque. It is the was built by al Darwish, the governor of Damascus in 1578.

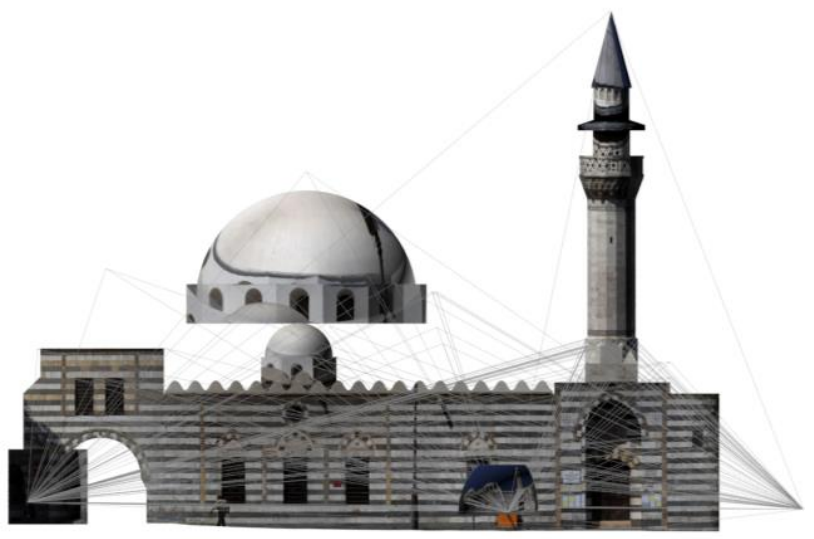

Figure 7 -al Darwikiya Mosque (plot and photomadeling by W.Wahbeh with three panoramas)

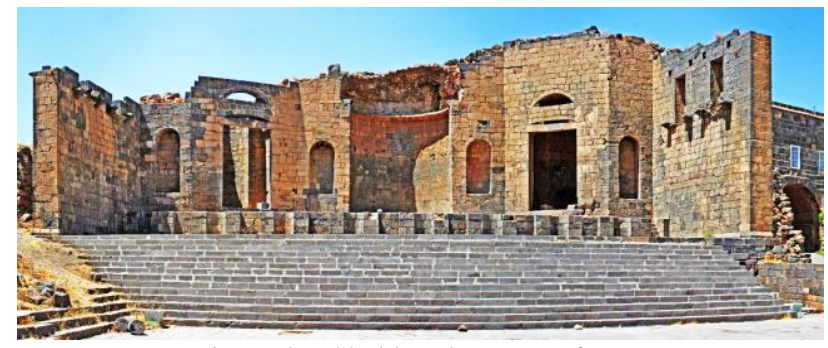

Figure 8 - Shabba, the roman forum

In Shabba born Philip the Arab, a Roman emperor of the $3^{\text {rd }}$ century, who build many magnificient pubblic buildings.

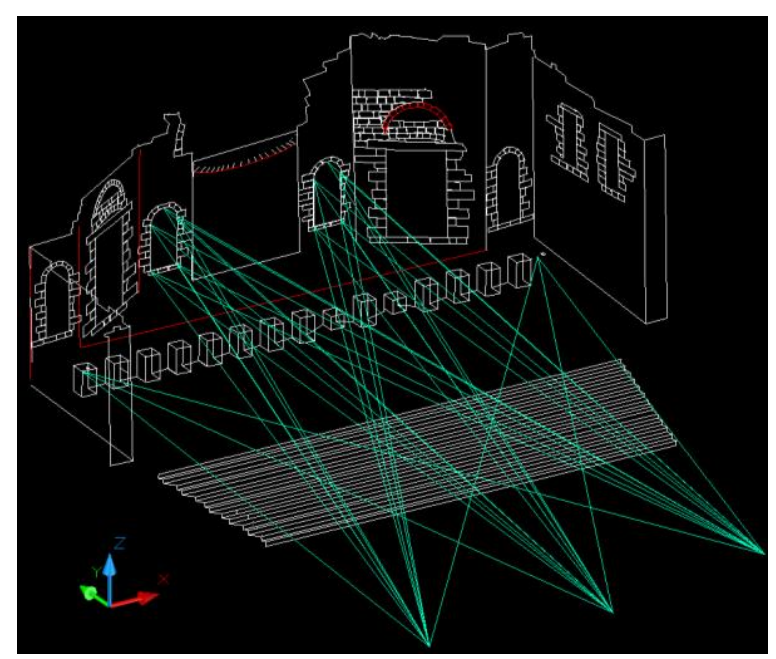

Figure 9 - Shabba the ancient forum (plot by V.Cori). The three panoramas points are visible together with the orientation directions.

Bosra, once the capital of the Roman province of Arabia, was an important stop on the ancient caravan route to Mecca. The splendid 2nd-century Roman theatre, made in black basalt, is one of the largest in the world, it is also the best preserved, because it was enclosed within a medieval fortification.

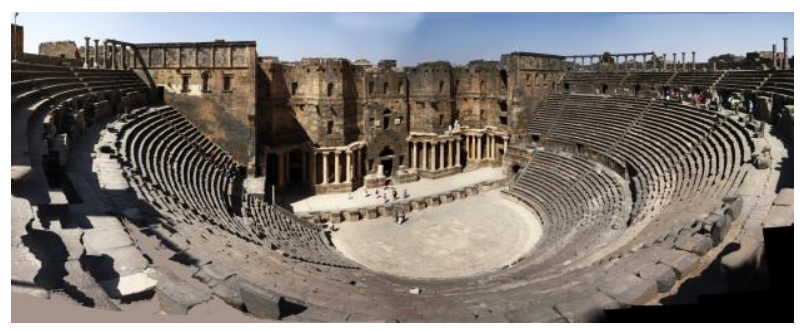

Figure 10 - Bosra, the Roman Theatre

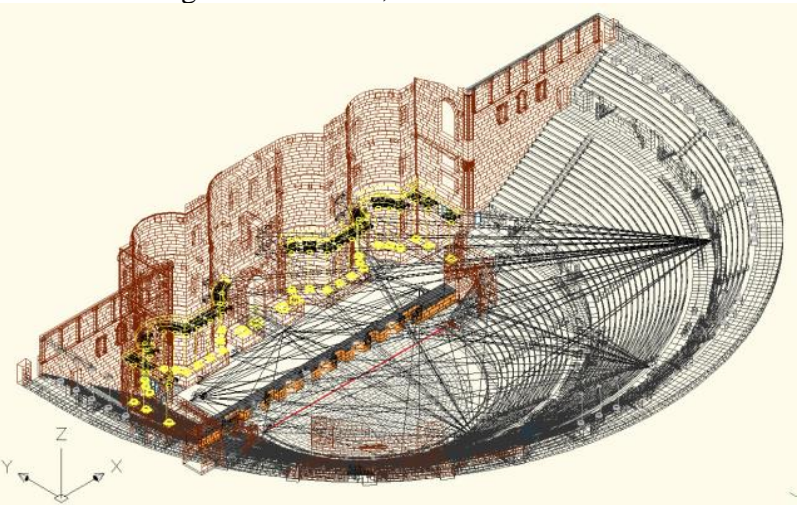

Figure 11 - The Roman theatre of Bosra (plot by S.Freddo) 


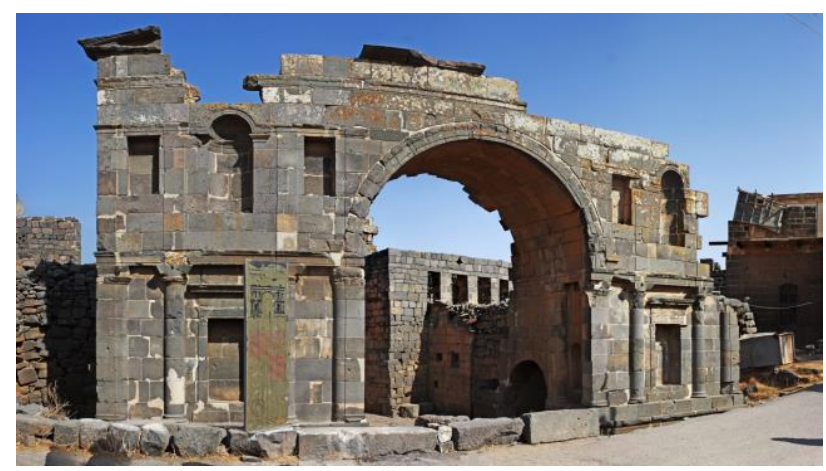

Figure 12 - Bosra, the Nabatean Arch

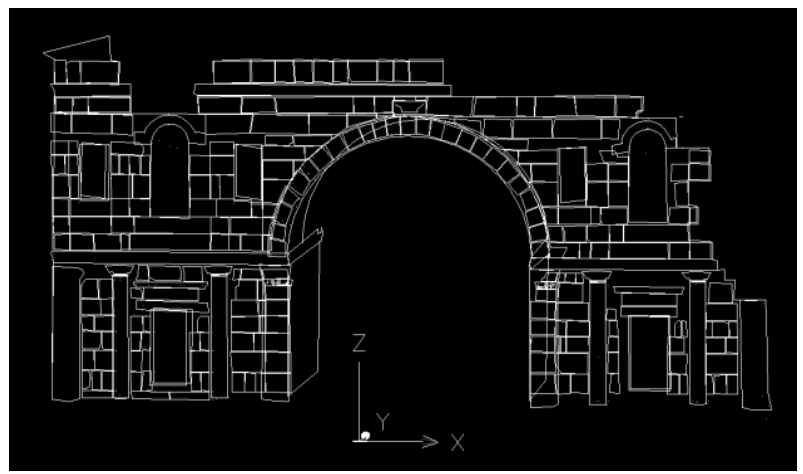

Figure 13 - The Nabatean Arch (plot by P. Biagiola) with five panoramas

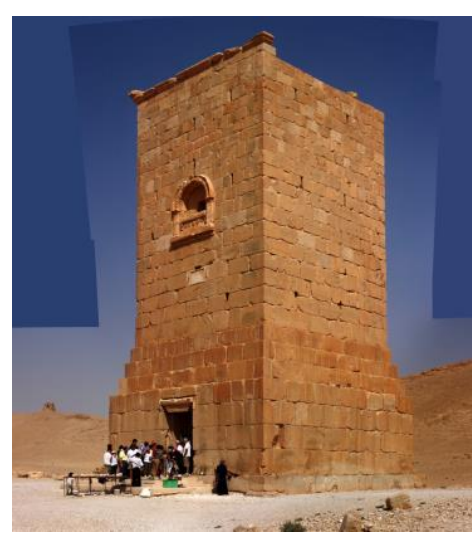

Figure 14 - Palmira a monumental tomb, one of the twelve panoramas sorrounding the monument

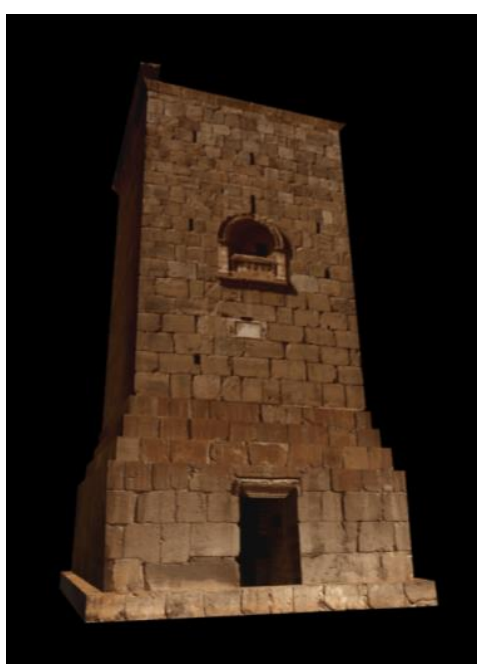

Figure 15 - Monumental tomb (Plot and render by M.Franca) http://youtu.be/1flZFgsmOzY

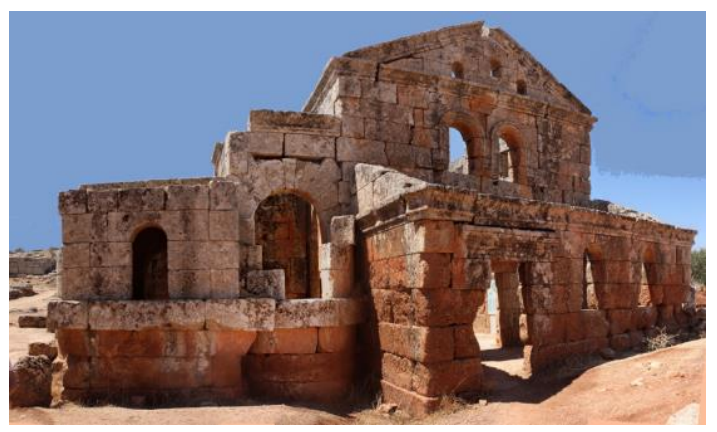

Figure 16 - Serjilla the dead city

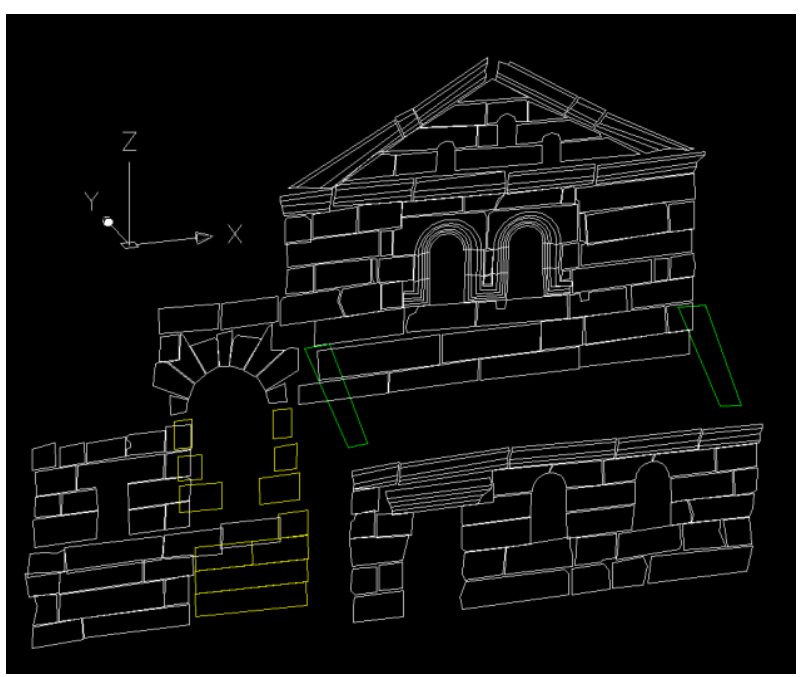

Figure 17 - Serjilla (Plot by E.Cingolani with two panoramas) 


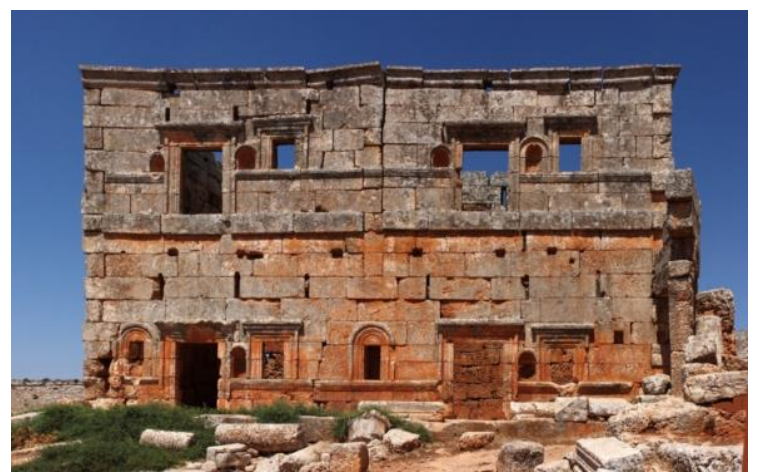

Figure 18 - Serjilla the dead city

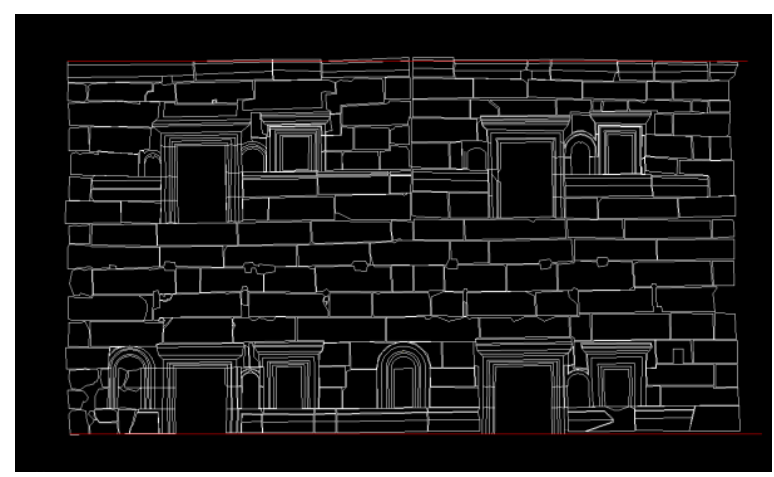

Figure 19 - Serjilla (plot by E.Cingolani with two panoramas)

Serjilla was a Byzantine settlement and is one of the best preserved ancient cities in the limestone massif in the northwest of Syria. Nowday it is called "a dead city".

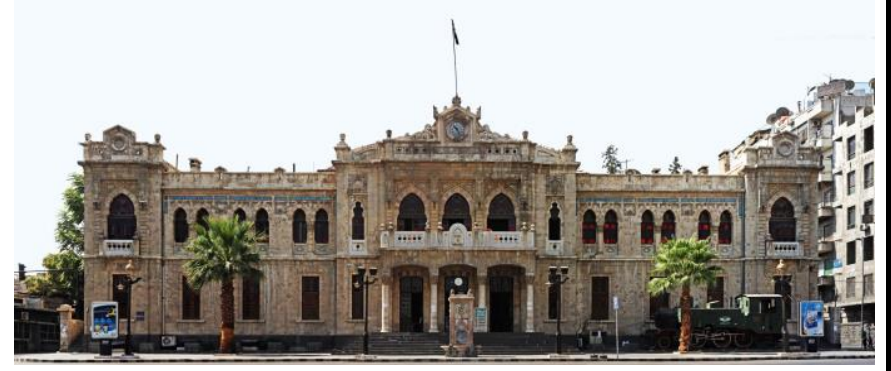

Figure 20 - Damascus, the ottoman railway station

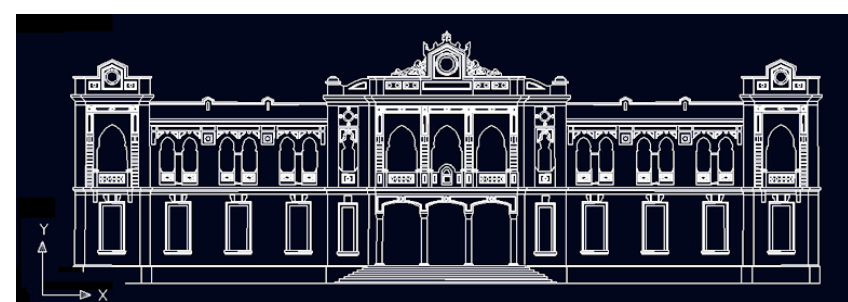

Figure 21 - The Ottoman Railway Station (Plot by C. Olimpio from five panoramas)

The ottoman railway station in Damascus, built during the ottoman empire, was connecting Istanbul to the Holy City Mecca. The restored façade was regarded as a masterpiece of ottoman architecture.

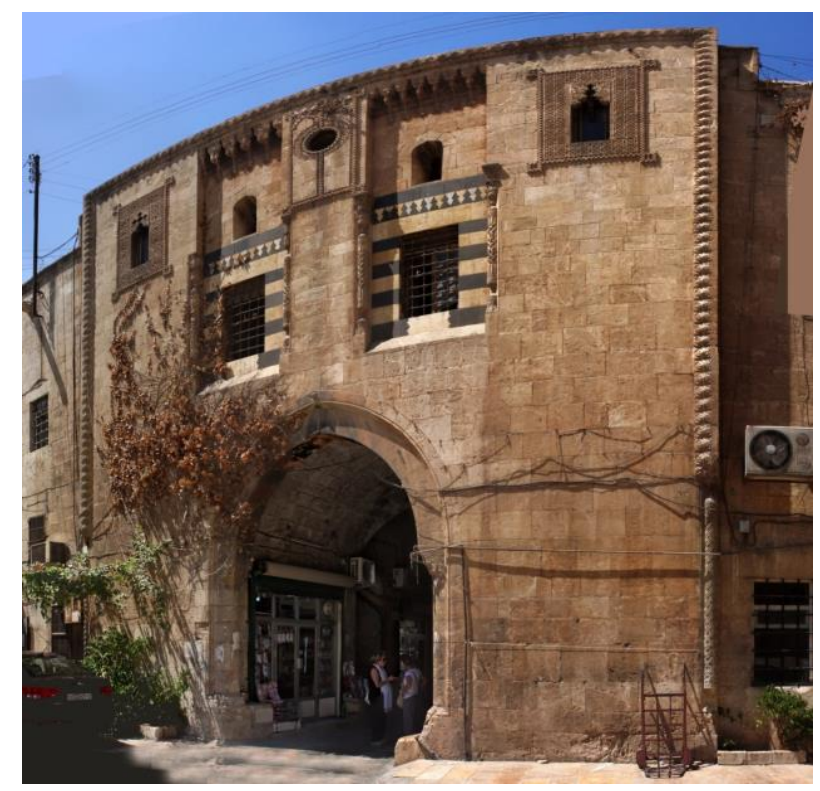

Figure 22 - Aleppo, Khan el Wasir gate

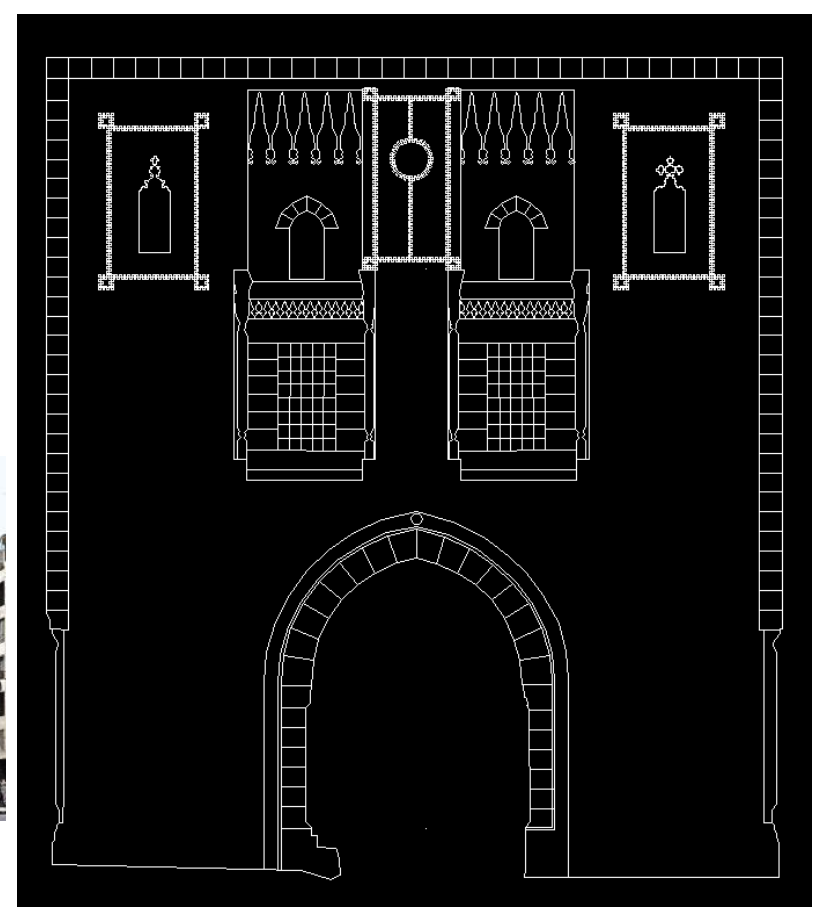

Figure 23 - Khan el Wasir (plot by V.Massacci with three panoramas) 


\section{THE REGULAR SURVEYS}

\subsection{The Umayyads Mosque in Damascus}

The large mosque, in the heart of the city, was built in 705 when Damascus was the capital of the Arab Islamic.

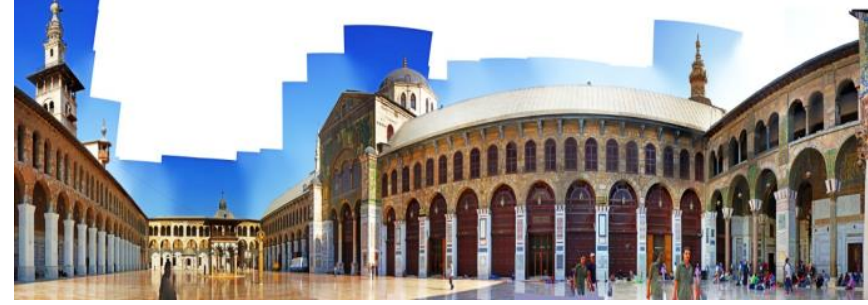

Figure 24 - Damascus, the Omayyad mosque

A regular network of panoramas was established inside the courtyard and outside the walls of the mosque. After the orientation of the panoramas, wire-frame plot of the coutyard only, including the three minaret, (Jesus, Bride, Al Quayat) took place, followed by the rendering.

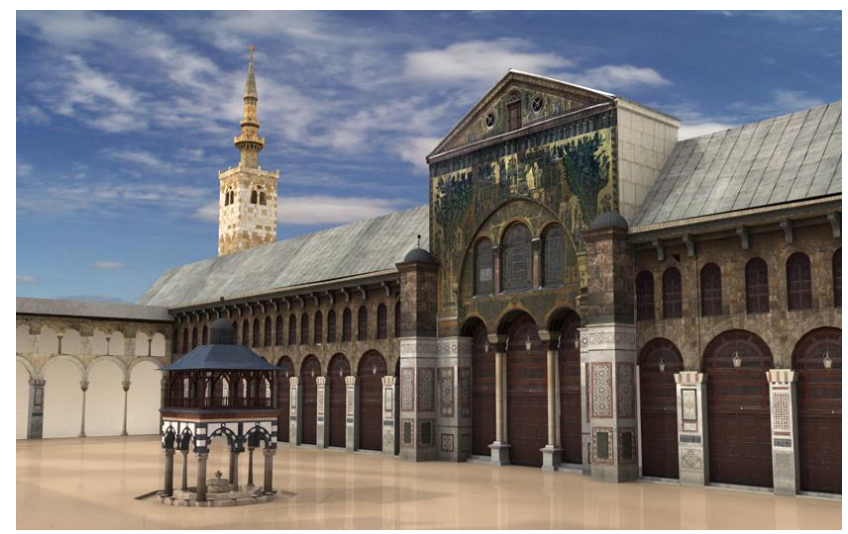

Figure 25 - The Umayyads mosque (plot and render by E.Cingolani)

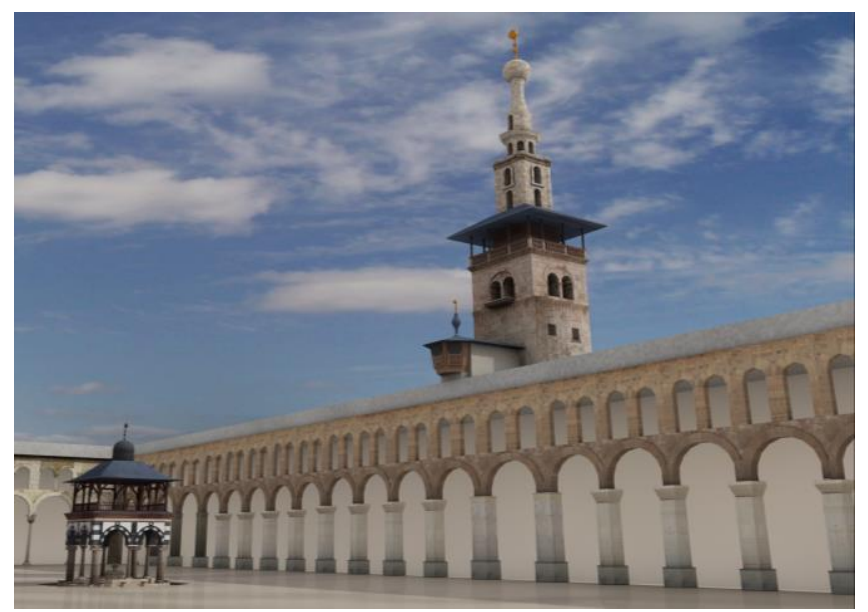

Figure 26 -Northern side of the coutyard with the bride minaret (plot and render by E.Cingolani)

https://www.youtube.com/watch?v=6yct7Uzk2Bo

\subsection{The walls of the Citadel in Aleppo}

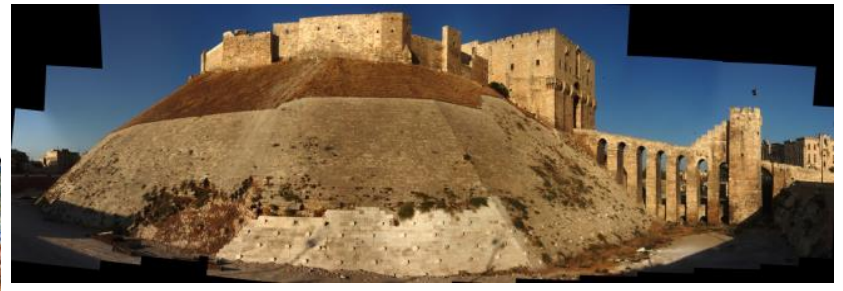

Figure 27 - Aleppo the Citadel walls before the war

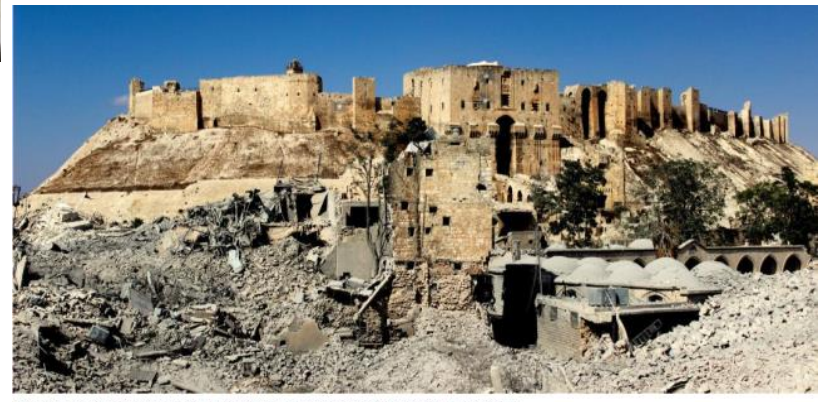

Figure 28 - Aleppo the Citadel walls during the war (photograph taken 14/8/14 ICC)

The total length of the walls is about $900 \mathrm{~m}$. The survey was performed with tripod, spherical head, $50 \mathrm{~mm}$ and $200 \mathrm{~mm}$ focal lenses. We could dimension the survey with the help of Google Earth high resolution.

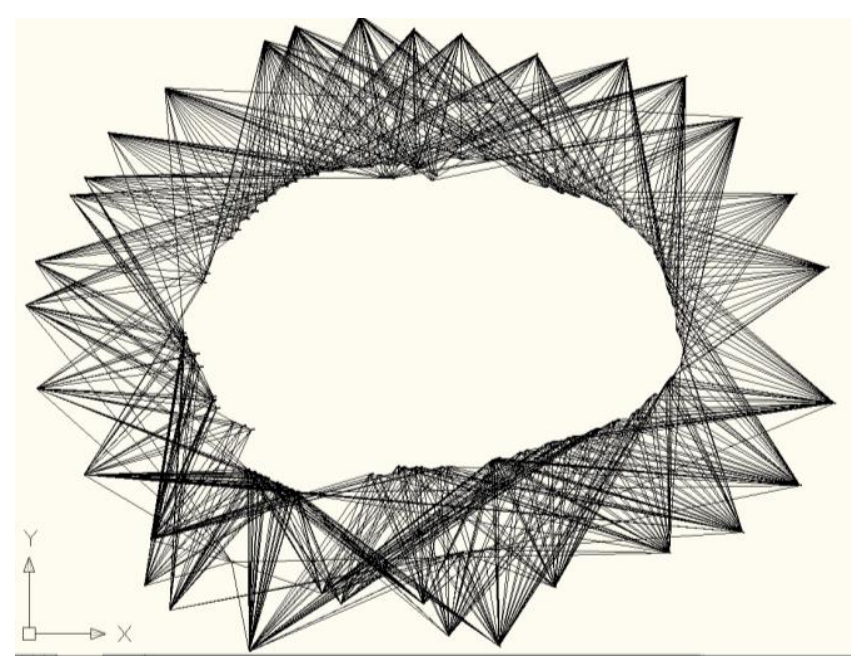

Figure 29 - The lay-out of the 36 panoramas around the Citadel

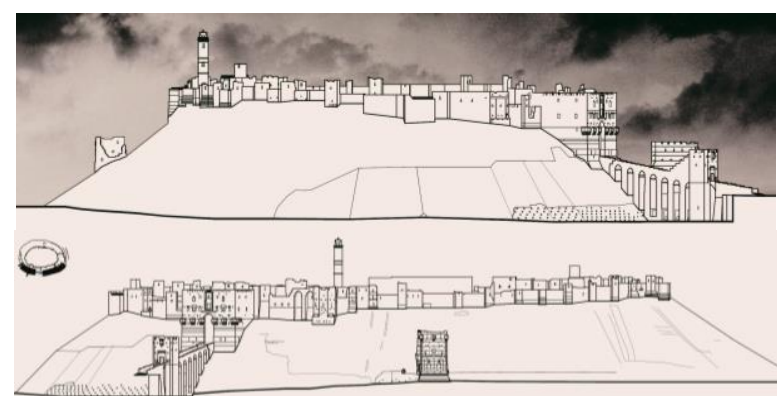


Figure 30 - The Citadel walls (plot by L.Piermattei)

The photographs have been shot with a Canon 60D and 50mm focal lens.

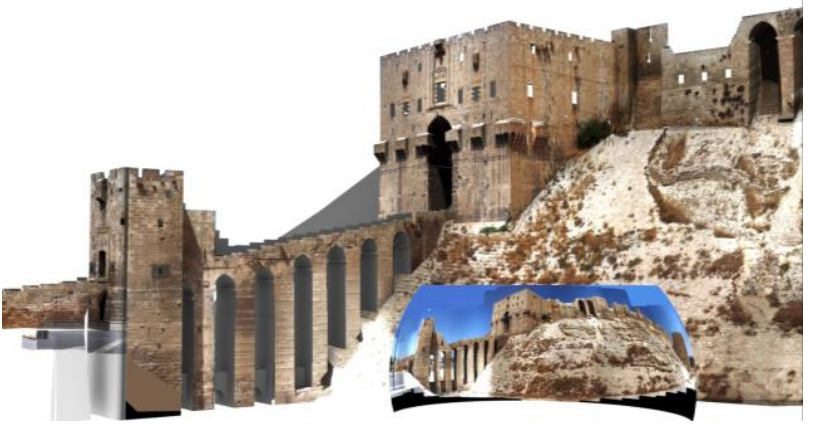

Figure 31 - The entrance gate (photomodelling by W.Wabeh)

\subsection{The Minaret of the Umayyads Mosque in Aleppo}

The war destroied the old minaret of the Umayyads Mosque in Aleppo, built in 1092 in very good conditions.

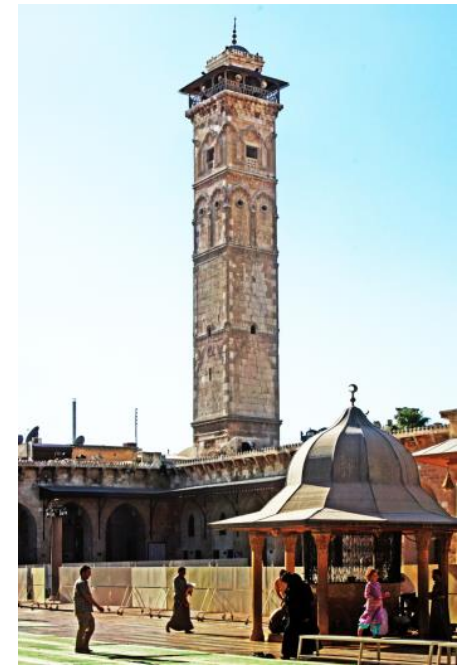

Figure 32 - Aleppo, the destroyed minaret of the Umayyads mosque. It was $45 \mathrm{~m}$ high and it was one of the most significant examples of Seljuk architecture, perfectly restored.

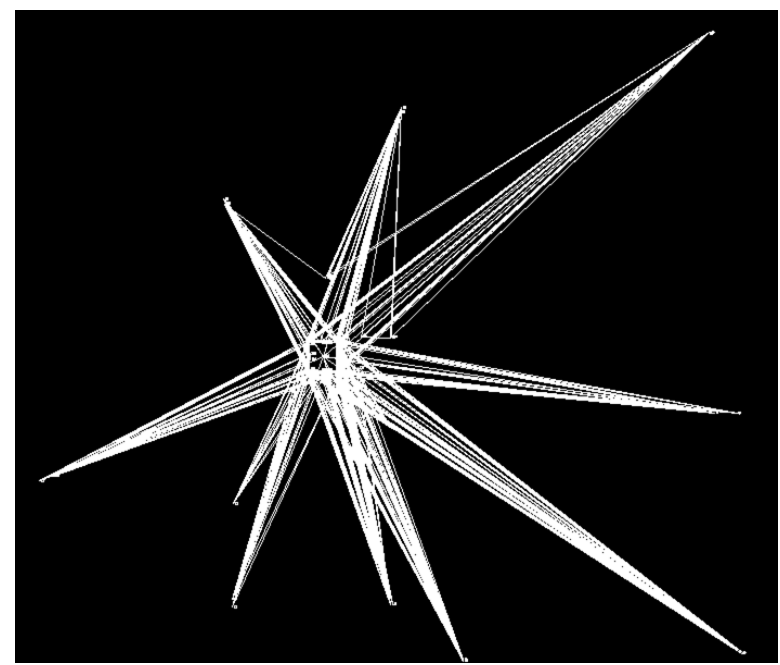

Figure 33 - The lay-out of the orientation network of the 22 panoramas

The 22 panoramas around the 900 years old minaret have been taken with the technique of double station: from the same station point two different panoramas have been shot, one with wide-angle lens and the other one with tele-lens. The orientation of tele pano can be helped by the orientation of the wide angle one, althought this last has less information. Any lens plays a different and useful role. After the wire-frame model, the solid midel was then covered and textured with the rectified images, to produre a very realistic model, using he same photographs of the panoramas.

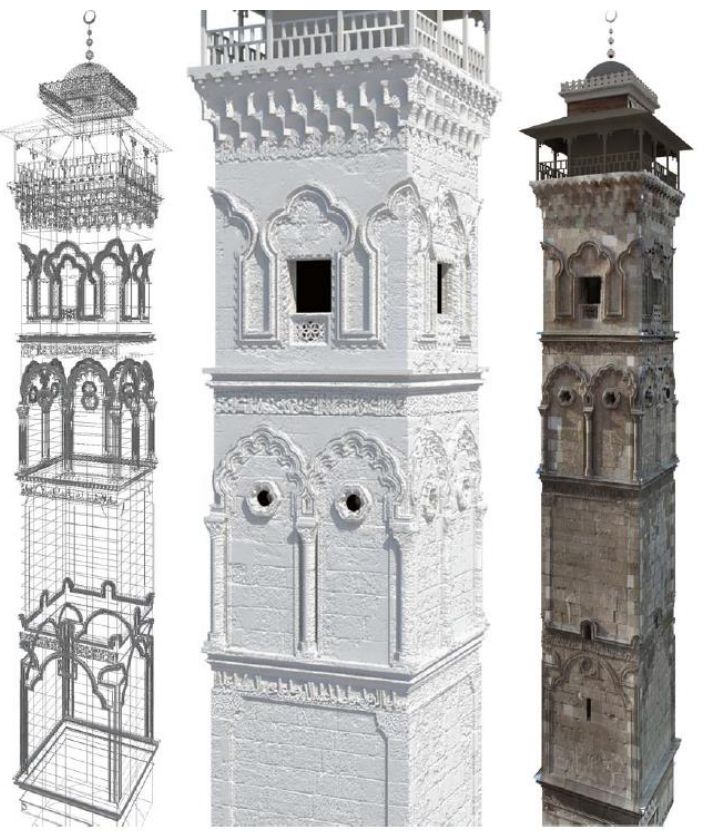

Figure 34 - Wire-frame, solid model and render (by W.Wahbeh and A.Aboufares)

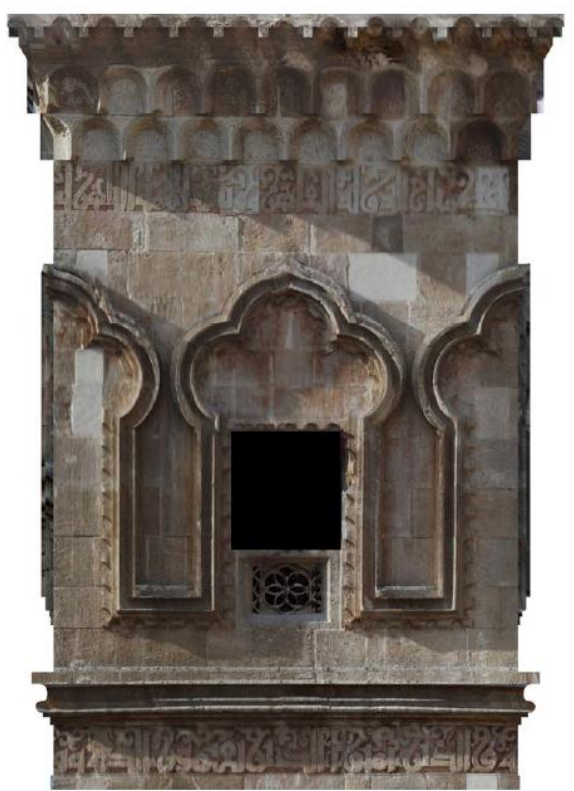

Figure 35 - A detail of the minaret from the textured 3D model (orthographic rendering) (by W.Wahbeh and A.Aboufares) 


\section{CONCLUSIONS}

Three rigorous surveys (with tripod, spherical head, $3 \times 3$ Cipa rules) say the Omayyad mosque in Damascus, the walls of the Citadel in Aleppo, the minaret of the mosque in Aleppo, have been performed. All the other surveys have been carried out in a less rigorous manner: the scale was taken from Google earth high resolution (when available) and the photographs have been shot with free hand-held camera. Nevertheless they could be still useful, since the accuracy seems to be enough good. All surveys are partial surveys only. Spherical Photogrammetry is a low-cost technique, the equipment consisting only in a digital camera, a tripod and a longimeter, there is no need of monumentation or targeting, the speed of taking is high. Therefore Spherical Photogrammetry can be regarded as emergency or rescue photogrammetry. All the produced material, photographs, computer software, plotting are available to the community in view of the reconstruction of $\mathrm{CH}$ in Syria. Considering the results, one might say that every administration should ensure the coverage of all its monuments with spherical panoramas, which is cheap, fast, procticable by anyone who knows how to take pictures.

\section{ACKNOWLEDGEMENTS}

The A. thanks all the mentioned students for their help. All the restitutions, the plottings, the renders have been done by the students of the course of Photogrammetry at the Universita Politecnica della Marche, Ancona, Italy. They are Francesco Di Stefano, Pierfrancesco Biagiola, Serena Freddo, Chiara Olimpio, Valentina Massacci, Anas Aboufares, Elisa Cingolani, Livia Piermattei, Veronica Cori, Marco Franca. A special thank to Wissam Wahbeh, a Syrian architect, that is now doing the doctorate in Roma La Sapienza University.

\section{REFERENCES}

Brusasco P. 2012 - LOOTING THE PAST Syria's cultural heritage under attack: another Iraq? Libreriauniversitaria, Padova

Fangi G., 2010. Multiscale Multiresolution Spherical Photogrammetry With Long Focal Lenses For Architectural Surveys -ISPRS Mid-term Symposium NewCastle, June 2010 ISSN 1682-1777 ID 585

Fangi, G. and Pierdicca, R., 2012. Notre Dame du Haut by spherical photogrammetry integrated by point cloud generated by multi view software. International Journal of Heritage in the Digital Era, 1(3): 461- 479.

Fangi G., Wahbeh W., Piermattei L., 2013. Spherical Photogrammetry as Rescue Documentation for The Reconstruction of some UNESCO Sites in Syria - International Journal of Heritage in the Digital Era - Publisher Multi Science Publishing - ISSN 2047-4970 - Volume 2, N.3 /September 2013 Pages 335- 342 - DOI 10.1260/2047-4970.2.3.335 - ID 156110

Pisa,C.,Zeppa, F. and Fangi, G., 2010. Spherical photogrammetry for cultural heritage. Proceeding of the Second Workshop on Heritage and Digital Art Preservation, Florence, Italy. 3-6.
De Amorim A. L., Fangi G., Malinverni E. S. - Documenting Architectural Heritage In Bahia, Brazil, Using Spherical Photogrammetry - XXIV International CIPA Symposium- Int. Arch. Photogramm. Remote Sens. Spatial Inf. Sci., XL-5/W2, 219-224, 2013 - doi:10.5194/isprsarchives-XL-5-W2-219-2013

Cingolani E., Fangi G.(2011) - Combined adjustment with spherical panoramas, and non metric images for long range survey, the San Barnaba Spire, Sagrada Familia, Barcelona, Spain-Cipa , Prague 2011, settembre ISSN: 1802-2669 - ID 63759

Fangi G. (2013) - Spherical Photogrammetry For Cultural Heritage Metric Documentation: A Critical Examen Six Years After The Beginning -A dimensao urbana do patrimonio Encontro Internacional Arquimemoria 4 - 14- 17 may 2013 1.ed Salvador IAB -BA 2013 360p - ISBN 978-85-66843-00-2 - / ISBN 978-85-66843-01-9 DVD - ID 156123

Fangi G., Nardinocchi C., 2013. Photogrammetric processing of spherical Panoramas - The Photogrammetric Record 28(143): 293-311, DOI: 10.1111/phor.12031 pg. 293- 311 @ 2013 The Remote Sensing and Photogrammetry Society and John Wiley \& Sons Ltd - ID 146702 2-s2.0-84883817879

Galán Rodrigo Martín - Syrian Historical Heritage Under Threat http://www.predella.it/index.php/current-

Franklin Lamb ,2012 - Syria's Endangered Heritage, An international Responsibility to Protect and Preserve is in production by Orontes River Publishing, Hama, SyrianArabRepublic.Inquires c/oorontesriverpublishing@gmail.com.

http://www.unesco.org/new/en/safeguarding-syrian-culturalheritage/situation-in-syria/built-heritage/

Borghese B. (2015) - Fostering Values to Protect Cultural Heritage ICC - Internation Institute for Conservation of historic and artistic works - https://www.iiconservation.org/ 